Short Communication

\title{
Vitality and Implication of Natural Products from Viburnum Grandiflorum: an Eco-Friendly Approach
}

\author{
Muhammad Suleman', Shazia Nouren², Syeda Mona Hassan ${ }^{3}$, Abul Hassan Faiz ${ }^{4}$, \\ Ghulam Abbas Sahr ${ }^{5}$, Gul Afshan Soomro5, Muhammad Asif Tahir6, \\ Munawar Iqbal ${ }^{7}$, Arif Nazir ${ }^{7 *}$ \\ ${ }^{1}$ Department of Chemistry, Women University of Azad Jammu \& Kashmir Bagh, Pakistan \\ ${ }^{2}$ Department of Chemistry, Govt. College Women University, Sialkot, Pakistan \\ ${ }^{3}$ Department of Chemistry, Lahore Garrison University, Lahore, Pakistan \\ ${ }^{4}$ Department of Zoology, Women University of Azad Jammu \& Kashmir Bagh, Pakistan \\ ${ }^{5}$ Institute of Chemistry, Shah Abdul Latif University, Khairpur 66020, Sindh, Pakistan \\ ${ }^{6}$ Department of Chemistry, University of Agriculture, Faisalabad, Pakistan \\ ${ }^{7}$ Department of Chemistry, The University of Lahore, Lahore-Pakistan
}

Received: 18 July 2017

Accepted: 3 September 2017

\begin{abstract}
In this study we screened Viburnum grandiflorum for bioactive secondary metabolites and biological activity. Secondary metabolites were detected by phytochemical tests, and biological activity was confirmed through antimicrobial and anti-oxidant assays. Phytochemical screening (alkaloidal, tannins, terpenoids, flavonoids, anthraquinones, and glycosides) was performed with methanol, and aqueous and ethyl acetate extracts. Antibacterial activity against four bacterial strains - staphylococcus auries, Escherichia Coli, Bacillus subtillus, and salmonella typhi - were measured. Methanolic extract showed maximum inhibitory activity with diameter of zone of inhibition $(11.66 \mathrm{~mm})$, followed by n-hexane extract $(9.33 \mathrm{~mm})$ and then ethyl acetate extract. Four different fungi (Penicillium chrysogenum, Aspergillus flavus, Rhodotorula mucilaginosa, and Stachybotrys chartarum) were also tested against plant stem extract using different solvents. Dimethyl sulfoxide extract showed a maximum zone of inhibition at 20 $\mathrm{mg} / \mathrm{ml}$. Anti-oxidant activity of stem extract of Viburnum grandiflorum was evaluated by 1, 1-diphenyl2-picryl-hydrazyl (DPPH). Then we measured absorbance, and percentage activity at each concentration was found for three solvent extracts to get Ic50 values. These data support Viburnum grandiflorum as having enough potential to be used safely as an antimicrobial drug.
\end{abstract}

Keywords: natural products, phytochemical, secondary metabolites, antimicrobial, fungi, bioactivity

*e-mail: anmalik77@gmail.com 


\section{Introduction}

Caprifoliaceous is a small family of about 12 genera and 450 species [1]. In recent classifications on molecular phylogeny the genus Viburnum (Caprifoliaceae) was put in the Adoxaceae family [2]. It has spread from South America to Southeast Asia, and the majority are found in a particular place [3]. It is found mostly in the temperate regions of the northern hemisphere. Its 4 genera and 27 species are found in Pakistan [4]. Six species of the genus Viburnum ( $V$. opulus, V. cylindricum, V. grandiflorum, $V$. mullaha, $V$. cotinifolium, and $V$. tinus) are commonly present in Pakistan [5]. Viburnum grandiflorum Wall ex D.C. has been used for treating wounds and malaria, and as a diuretic [6]. Viburnum grandiflorum is used locally to cure abdominal pain and as a purgative [7], antimalarial, and diuretic [8]. It is also used as a wound curative [9], and to treat upset stomachs [8, 10], whooping cough, respiratory diseases, toothaches, and typhoid [11], and as an anesthetic [12]. Uddin et al. [5] studied the conventional system of medicine and the role of Viburnum grandiflorum as an antipyretic in the treatment of typhoid and malaria. Uddin and his co-workers also performed scientific justification of the anti-inflammatory, anti-nociceptive, and antipyretic effects of $V$. grandiflorum with respect to its chemical composition. Viburnum species are also used for treating different diseases such as diarrhoea, rheumatoid arthritis, tumefaction, anti-diabetic, antioxidant and anti-bacterial [13-14]. The present study was undertaken to investigate the phytochemical composition and antioxidant and antimicrobial properties of the stem parts of $V$. grandiflorum.

\section{Materials and Methods}

Viburnum grandiflorum stem was collected locally from the Bagh Azad Kashmir District in Pakistan and dried in the shade. Dried stems were converted to powder by means of an electric grinder. Powder ( $10 \mathrm{~g})$ was soaked in methanol in Erlenmeyer flasks for three days with continuous shaking. Extract was filtered and filtrate was evaporated to obtain dried extract that was stored at $4^{\circ} \mathrm{C}$.
Phytochemical Analysis was performed following the methods reported in Tadesse et al. [15], and antibacterial assay was determined by the procedure described by Iqbal et al. [16].

Sabouraud dextrose agar (SDA) (65 g in 1,000 ml) was prepared for fungal growth (Penicillium chrysogenum, Aspergillus flavus, Rhodotorula mucilaginosa, and Stachybotrys chartarum). SDA was autoclaved at $121^{\circ} \mathrm{C}$ for 15 minutes, cooled to $45-50^{\circ} \mathrm{C}$, and $20 \mathrm{ml}$ of molten SDA medium was aseptically transferred into each sterilized petri plate. $150 \mu \mathrm{l}$ fungal suspensions were spread uniformly over the agar in petri dishes using a sterile glass rod. Filter paper discs were prepared and soaked with different dilutions of plant extract, and one disc was soaked with water for negative control. Aseptically, the soaked discs were transferred to the inoculated plates with the help of sterile forceps. An antifungal disc and a water-soaked disc were placed in the plate for positive control and negative plate, respectively. The plates were incubated for 24 hours at $37^{\circ} \mathrm{C}$. After 24 hours fungal growth was observed in the petri plates and the diameters of zones of inhibition were measured. The antifungal activity was expressed as the mean of diameter of the inhibition.

For thin layer chromatography (TLC), a small spot of methanolic extract of Viburnum grandiflorum was applied to a plate about 1.5 centimeters from the bottom edge. Solvents used for TLC were ethyl acetate, methanol, n-hexane, dichloromethane, ethyl acetate + methanol, dichloromethane + n-hexane, and dichloromethane + methanol. The TLC plate was then placed in the chamber so that the spot(s) of the sample did not touch the surface of the eluent in the chamber, and the lid was closed. The plate was visualized using ultraviolet light and was sprayed by chemicals after elution.

For antioxidant activity, DPPH assay of the plant Viburnum grandiflorum was carried out as described in Bozin et al. [17]. The capability of scavenging the DPPH radical was calculated by using the following formula:

DPPH scavenging effect (\% inhibition)

$$
\left.=\left\{\left(\mathrm{A}_{0}-\mathrm{A} 1\right) / \mathrm{A}_{0}\right) \times 100\right\}
$$

Table 1. Antibiotic sensitivity activity of Viburnum grandiflorum-Guch stem's extract.

\begin{tabular}{|c|c|c|c|c|c|c|c|c|c|c|c|c|c|c|c|c|c|c|}
\hline \multirow{3}{*}{ Microorganism } & \multicolumn{6}{|c|}{ Methanol } & \multicolumn{6}{|c|}{ Hexane } & \multicolumn{6}{|c|}{ Ethyle acetate } \\
\hline & \multicolumn{18}{|c|}{ Concentrations of extracts used $(\mathrm{mg} / \mathrm{ml})$ / Zones of inhibition $(\mathrm{mm})$} \\
\hline & 5 & 10 & 15 & 20 & A & $\mathrm{W}$ & 5 & 10 & 15 & 20 & A & W & 5 & 10 & 15 & 20 & A & W \\
\hline $\begin{array}{c}\text { Staphylococcus } \\
\text { aureus }\end{array}$ & NZ & 6 & 9.8 & 11.6 & 26 & NZ & NZ & 6.33 & 8.33 & 9.33 & 26 & $\mathrm{NZ}$ & NZ & NZ & 6.3 & 8 & 26 & $\mathrm{NZ}$ \\
\hline Escherichia Coli & NZ & $\mathrm{NZ}$ & 7 & 8 & 26 & NZ & 5 & 7.33 & 8.33 & 9 & 26 & $\mathrm{NZ}$ & NZ & $\mathrm{NZ}$ & 7.33 & 8 & 26 & NZ \\
\hline Bacillus Subtilus & $\mathrm{NZ}$ & 6 & 7.3 & 8.3 & 25 & NZ & NZ & 5 & 6.33 & 7.33 & 25 & $\mathrm{NZ}$ & 6 & 10.2 & 12 & 12.3 & 25 & $\mathrm{NZ}$ \\
\hline $\begin{array}{l}\text { Salmonella } \\
\text { entererous }\end{array}$ & $\mathrm{NZ}$ & $\mathrm{NZ}$ & 8 & 9 & 25 & $\mathrm{NZ}$ & $\mathrm{NZ}$ & NZ & $\mathrm{NZ}$ & $\mathrm{NZ}$ & 25 & NZ & $\mathrm{NZ}$ & $\mathrm{NZ}$ & $\mathrm{NZ}$ & $\mathrm{NZ}$ & 25 & $\mathrm{NZ}$ \\
\hline
\end{tabular}

NZ: no zone, A: standard antibiotic, W: Water 
...where $\mathrm{A}_{0}$ is the absorbance of the control reaction and $A_{1}$ is absorbance in the presence of all the extract samples and reference. All tests were performed in triplicate.

\section{Results and Discussion}

Phytochemical screening of Viburnum grandiflorum Guch stem's extract was performed for the recognition of secondary metabolites. Phytochemical screening was performed with methanolic, n-haxane, and ethyl acetate extract. The results revealed the presence of tannins and glycosides in all extracts, terpenoids, and saponins in methanolic and ethyl acetate extract and anthraquinones in ethyl acetate extract only. The results of the phytochemical screening are in line with the study conducted by Uddin et al. [5]. In their work they showed the presence of bioactive secondary metabolite constituents such as terpenoids, steroids, anthraquinones, flavonoids, and saponins [5].

The biological activity of $V$. grandiflorum-Guch stem's extract was confirmed through antibacterial assay. Table 1 shows the anti-bacterial activity of Viburnum grandiflorum-Guch stem's extract against Gram-positive bacteria (Staph aureus and B. subtilis) and Gramnegative bacteria (E.coli and S. enterocous) at different concentrations. Low concentrations of extract showed less anti-bacterial activity while in increasing concentrations anti-bacterial activity also increased. Samples with least concentration of extract showed no inhibitory activity. For Staph aureus the methanolic sample with the highest concentration $(20 \mathrm{mg} / \mathrm{ml})$ showed maximum inhibitory activity with diameter of zone of inhibition (DIZ) (11.66 $\mathrm{mm})$. For E. Coli, n-hexane extract showed maximum inhibitory effect with highest DIZ ( $9 \mathrm{~mm})$. Ethyl acetate extract showed maximum inhibition against Bacillus subtillus having DIZ (12.33 mm). Against S. typhi. only methanolic extract showed an inhibitory effect at higher concentrations with DIZ (9 mm). Uddin and his coworkers [5] checked antibacterial activity of $V$. grandiflorum extracts in (Methanol, n-hexane, ethyl acetate, and chloroform). At $22 \mathrm{mg} / \mathrm{ml} \mathrm{DIZ} \mathrm{the} \mathrm{results} \mathrm{were} \mathrm{20,} \mathrm{15,}$ and 14 for Methanol, n-hexane, and ethyl acetate solvents, respectively $[5,18]$. In another study Ganjewala and Gupta showed the highest antibacterial activity with methanolic extract of $V$. grandiflorum at concentrations of $50 \mathrm{mg} / \mathrm{ml}$ and $100 \mathrm{mg} / \mathrm{ml}$ with DIZ from 13-21 $\mathrm{mm}$ [19].

Table 2 shows the anti-fungal activity of Viburnum grandiflorum-Guch stem's extract against a fungus named penicillium chrysogenum, Aspergillus flavus, Rhodotorula mucilaginosa, and Stachybotrys Chartarum. Meconazole was used as anti-fungal for positive control, and water was placed as negative control. Only dimethyl sulf-oxide extract exhibited an inhibitory effect against these fungal species, while methanol, n-hexane, and ethyl acetate extract showed no inhibition. Dimethyl sulf-oxide extract exhibited maximum inhibitory effect against this fungus having DIZ $12.66 \mathrm{~mm}$ (penicillium chrysogenum), 11.66 (Aspergillus flavus), $12 \mathrm{~mm}$

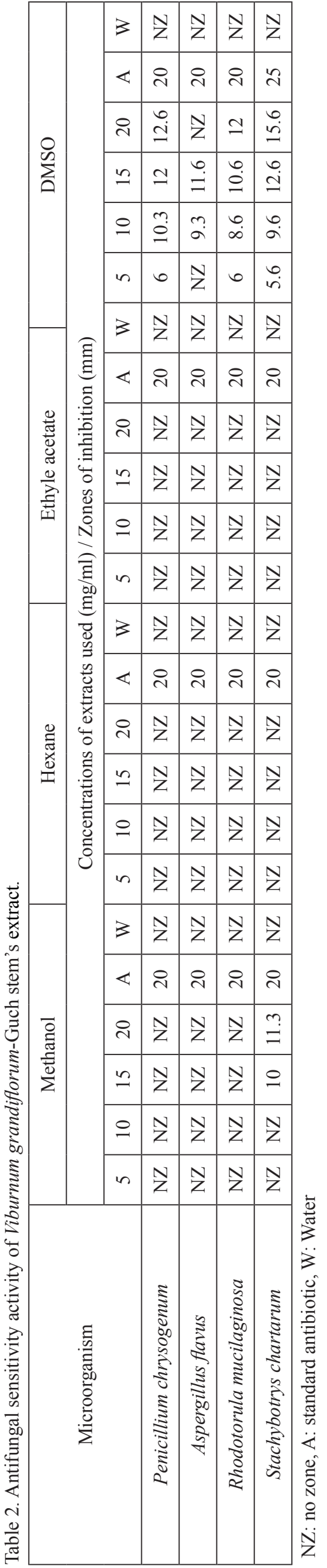


(Rhodotorula mucilaginosa), and $15.66 \mathrm{~mm}$ (Stachybotrys Chartarum). Methaolic extract also showed an inhibitory effect on Stachybotrys Chartarum with diameter of zone of inhibition (11.33 $\mathrm{mm})$.

The results are also in line with Alam et al. [13], who checked the antifungal activity of $V$. grandiflorum stem's ethanolic extracts in methanol, n-hexane, ethyl acetate, and chloroform against Aspergillus flavus, and no activity was found for these solvents. In another study they also found antifungal activity of $V$ grandiflorum ethanolic extracts of its oil in DMSO against Aspergillus flavus [20]. TLC was also performed by using different solvent systems. Ethyl acetate, ethanol, n-hexane, dichloromethane, and ethyl acetate were used at $100 \%$ concentrations each or $50 \%$ concentrations. The total number of components detected from the stem's extract is: 7, 3, 1, 5, 6, 4, and 6, respectively. Maximum components were detected by the ethyl acetate solvent system.

The free radical scavenging activity of extracts of $V$ grandiflorum-Guch stems was evaluated by 1 , 1-diphenyl-2-picryl-hydrazyl (DPPH), and absorbance was measured at $517 \mathrm{~nm}$. Among the tested extracts the aqueous extract displayed the most potent antioxidant activity $(58 \%)$ at $400 \mathrm{mg} / \mathrm{ml}$ concentration, followed by ethyl acetate $(58 \%)$ at $600 \mathrm{mg} / \mathrm{ml}$ and methanol (33\%) at $250 \mathrm{mg} / \mathrm{ml}$. The lower concentration of extracts showed lower activity in different solvents, e.g., the lowest activity (14.10\%) was shown in ethyl acetate extract followed by methanolic extract $(24.24 \%)$ and aqueous extract $(25.84 \%)$ at $10 \mathrm{mg} / \mathrm{ml}$ concentrations. The higher concentration of the extracts showed higher percent activity, which may be due to using stem extract. The antioxidant potential of Viburnum grandiflorum showed better scavenging activity $(\mathrm{IC} 50=255 \mu \mathrm{g} / \mathrm{ml}$ ) in aqueous extract followed by ethyl acetate extract $(\mathrm{IC} 50=322 \mu \mathrm{g} / \mathrm{ml})$ and methanolic extract $(\mathrm{IC} 50=742$ $\mu \mathrm{g} / \mathrm{ml})$.

Medicinal plants are still widely used for conservation of biodiversity, traditional culture, drug development, and health care. Natural products obtained from different plant species possess a variety of biologically active compounds and are subsequently being tested for pharmacological activities. An ethnobotanical study of Viburnum Grandiflorum has been attempted to highlight its medicinal significance. It has been tested and shown to have antibacterial, antifungal, antimicrobial, antiseptic, anti-inflammatory, antioxidant, anti-malarial, and antirheumatic activities [22-29].

\section{Conclusions}

All phytochemicals were found to be present in all extracts. Methanol, n-hexane, and ethyl acetate extract showed no inhibition for the tested three fungi except Stachybotrys chartarum. Dimethyl sulfoxide extracts showed maximum inhibition followed by methanolic extract for Stachybotrys chartarum. Through TLC on stem extract, maximum components were detected by the ethyl acetate solvent system. Antioxidant activity of stem extract of Viburnum grandiflorum was evaluated by 1, 1-diphenyl-2-picry 1-hydrazyl (DPPH). This plant was selected due to the presence of different compounds of medicinal value and to determine the antimicrobial and antioxidant capacities of these compounds.

We have concluded that the aerial parts (stem) of $V$. grandiflorum can be safely used as antibacterial and antifungal drugs, and the recorded data of the study proves its importance as a potential antimicrobial drug.

\section{References}

1. DAEHLER C.C. The taxonomic distribution of invasive angiosperm plants: ecological insights and comparison to agricultural weeds. Biol. Conserv. 84 (2), 167, 1998.

2. FUKUYAMA Y., KUBO M., ESUMI T., HARADA K., HIOKI H. Chemistry and biological activities of vibsanetype diterpenoids. Heterocycles 81 (7), 1571, 2010.

3. BELL C.D., EDWARDS E.J., KIM S.T., DONOGHUE M.J. Dipsacales phylogeny based on chloroplast DNA sequences. Harvard Papers Bot. 481, 2001.

4. PERVEEN A., QAISER M. Pollen flora of Pakistan-LV. Caprifoliaceae. Pak. J. Bot. 39 (5), 1393, 2007.

5. UDDIN G., ALAM M., MUHAMMAD N., SIDDIQUI B.S., SADAT A. Bioassay-guided Isolation of a Antinociceptive, Anti-inflammatory and Antipyretic Benzofuran Derivative from Viburnum grandiflorum. Pharm. Anal. Act. 2013.

6. SHAH Z., ALI F., ULLAH H., KHAN D., KHAN S., KHAN R., ALI I. Biological Screening and Chemical Constituents of Viburnum grandiflorum. J. Chem. Soc. Pak, 36, 113, 2014.

7. KUMAR M., PAUL Y., ANAND V. An ethnobotanical study of medicinal plants used by the locals in Kishtwar, Jammu and Kashmir, India. Ethnobot. Leaflet. 10, 5, 2009.

8. DAR M. Ethno botanical uses of Plants of Lawat District Muzaffarabad, Azad Jammu and Kashmir. Asian J. Plant Sci. 2 (9), 680, 2003.

9. NAUTIYAL S., MAIKHURI R., RAO K., SAXENA K. Medicinal plant resources in Nanda Devi Biosphere Reserve in the central Himalayas. J. Herbs, Spices Med. Plants 8 (4), 47, 2001.

10. LATIF A., SHINWARI Z., HUSSAIN J., MURTAZA S. NTFPS: An alternative to forest logging in Minadam and Sultanar Valley Swat. Lyonia 11, 15, 2006.

11. KHAN Z., KHUROO A., DAR G. Ethnomedicinal survey of Uri, Kashmir Himalaya. Indian J. Tradit. Know. 3 (4), 351, 2004.

12. BALANGCOD T.D., BALANGCOD A.K.D. Ethnomedical knowledge of plants and healthcare practices among the Kalanguya tribe in Tinoc, Ifugao, Luzon, Philippines. Indian J. Tradit. Know. 10 (2), 227, 2011.

13. ALAM M., UDDIN G., SADAT A., MUHAMMAD N., KHAN A.A., SIDDIQUI B.S. Evaluation of Viburnum grandiflorum for its in-vitro pharmacological screening. Afr. J. Pharm. Pharmacol. 6 (22), 1606, 2012.

14. SZCZEPAŃSKA N., OWCZAREK K., KUDŁAK B., POKRYWKA A., MAZERSKA Z., GAŁUSZKA A., NAMIEŚNIK J. Analysis and Bioanalysis: an Effective Tool for Data Collection of Environmental Conditions and Processes. Pol. J. Environ. Stud. 25 (1), 45, 2016.

15. TADESSE G., RENEELA P., DEKEBO A. Isolation And Characterization Of Natural Products From Helinus 
Mystachnus (Rhamnaceae). J. Chem. Pharm. Res. 4 (3), 1756, 2012.

16. IQBAL M., KHERA RA., HUSSAIN T., SADIA H., ABBAS M., NAZIR A., ARSHAD M., YOUNAS U. Cytotoxicity and bioactivity evaluation of pygmy date palm extracts. Cur. Sci. Perspect. 3 (2), 106, 2017.

17. BOZIN B., MIMICA-DUKIC N., SIMIN N., ANACKOV G. Characterization of the volatile composition of essential oils of some Lamiaceae spices and the antimicrobial and antioxidant activities of the entire oils. J. Agric. Food Chem. 54, 1822, 2006.

18. KOLKMANA A., SCHRIKS M., BRANDA W., BÄUERLEINA P.S., van der KOOI M.M.E., van DOORNA R.H., EMKE E., REUS A.A., van der LINDENC S.C., de VOOGT P., HERINGA M.B.Sample preparation for combined chemical analysis and in vitro bioassay application in water quality assessment. Environ. Toxicol. Phar. 36, 1291, 2013.

19. GANJEWALA D., GUPTA A.K. Study on Phytochemical composition, antibacterial and antioxidant properties of different parts of Alstonia scholaris Linn. Adv. Pharm. Bull. 3 (2), 379, 2013.

20. ALAM M., UDDIN G., SIDDIQUI B.S., SADAT A., KHAN A.A., RAUF A. Gas chromatography-mass spectrometry (GC-MS) analysis, antimicrobial, phytotoxic, insecticidal and leishmanicidal activities of fixed oil from Viburnum grandiflorum. Afr. J. Pharm. Pharmacol. 8 (46), 1173, 2014.

21. BHAGAT M., SUDAN R., GUPTA S., KAUL A., SINGH J. Antioxidant and Immunomodulatory Potential of Cobra lily Species of North-western Himalayan Region: A Comparative Analysis. J. Biol. Activ. Prod.Nat. 4 (3), 179, 2014.

22. AWAN ZI, REHMAN H, YASIN KA, MINHAS FA. A New Lupan type Triterpene Butilinol from Viburnum grandiflorum. IOSR J. Appl. Chem. 5 (4), 58, 2013.
23. AMJAD M.S., ARSHAD M. Ethnobotanical inventory and medicinal uses of some important woody plant species of Kotli, Azad Kashmir, Pakistan. Asian Pac. J. Trop. Biomed 4 (12), 952, 2014.

24. RANA P.K., KUMAR P., SINGHAL V.K. Spindle irregularities, chromatin transfer and chromatin stickiness during male meiosis in Anemone tetrasepala . Turkish J. Bot. 37, 167, 2013.

25. ARSHAD M., AHMED M., AHMED E., SABOOR A., ABBAS A., SADIQ S. An ethnobiological study in Kala Chitta hills of Pothwar Region, Pakistan: multinomial logit specification. J. Ethnobiol. Ethnomed. 10, 13, 2014.

26. AHMAD M., SULTANA S., FAZL-I-HADI S., HADDA T.B., RASHID S., ZAFAR M., KHAN M.A., KHAN M.P.Z., YASEEN G. An ethnobotanical study of medicinal plants in high mountainous region of Chail Valley (District Swat-Pakistan). J. Ethnobiol. Ethnomed. 10, 36, 2014

27. MURAD W., AHMAD A., ISHAQ G., KHAN M.S., KHAN A.M., ULLAH I., ULLAH A., KHAN I. Ethnobotanical studies on plant resources of Hazar Nao forest, district Malakand, Pakistan. Pak. J. Weed Sci. Res. 18 (4), 509, 2012.

28. AMJAD M.S., ARSHAD M., MALIK Z.H. An overview of human-plant interaction in Nikyal rangeland district Kotli Azad Jammu and Kashmir. Afr. J. Plant Sci. 7 (12), 571, 2013.

29. AKHTAR N., RASHID A., MURAD W., BERGMEIER E. Diversity and use of ethno-medicinal plants in the region of Swat, North Pakistan. J. Ethnobiol. Ethnomed. 9, 25, 2013. 